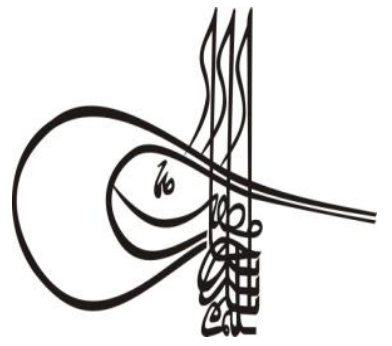

Received/Geliş: 25.06 .2019
Tutkish Studies

Volume 14 Issue 4, 2019, p. 2647-2658

DOI: 10.29228/TurkishStudies.23515

ISSN: 1308-2140

Skopje/MACEDONIA-Ankara/TURKEY

Research Article / Araștırma Makalesi

Article Info/Makale Bilgisi

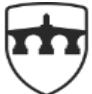

INTERNATIONAL BALKAN UNIVERSITY

EXCELLENCE FOR THE FUTURE IBU.EDU.MK

\Accepted/Kabul: 10.08.2019

Go Report Dates/Rapor Tarihleri: Referee 1 (24.07.2019)-Referee 2 (27.07.2019)

This article was checked by iThenticate.

\title{
RELATION BETWEEN TEACHERS' JOB SATISFACTION AND THEIR MOTIVATION FOR PROFESSIONAL DEVELOPMENT
}

\author{
Ismet POTERA* - Fatmir MEHMETI**
}

\begin{abstract}
The purpose of the research was to deepen the understanding of whether satisfaction with the work that teachers do motivates them to participate in different forms of professional development. Important factors were identified in this context that encourages teachers to participate in professional development. According to selfdetermination theory, SDT (Deci \& Ryan, 2000) are two motivational factors that drive an individual to be involved in actions, such as career development. Job satisfaction is an important motivating factor, where in the case of teaching the motivating factor, internal or external, appears to be mixed. Therefore it cannot be ascertained whether satisfaction is the most important motivational factor that influences teacher participation in forms of professional development. If students 'success as a result of quality teaching is considered as a form of teachers' satisfaction with their work then it emerges as an important factor in terms of gender $\quad(r=.24)$. This we have tried to do through quantitative research with a sample of teachers. The degree of job satisfaction and the increased demand / need for participation in various forms of continuous professional development assume that they are not reciprocally linked. Research is quantitative. The data was collected by the questionnaire. The sample consists of 170 teachers belonging to genders, low secondary school, rural and urban school.
\end{abstract}

\section{STRUCTURED ABSTRACT}

The purpose of the research was to deepen the understanding of whether satisfaction with the work that teachers do motivates them to participate in different forms of professional development. Important

Researcher in Kosovo Pedagogical Institute and $\mathrm{PhD}$ candidate at Faculty of Education, E-posta: smtpotera@yahoo.com

** ID Dr., Lecturer, University of Prizren, Faculty of Education, E-posta: fatmir.xh.mehmeti@gmail.com 
factors were identified in this context that encourages teachers to participate in professional development. According to self-determination theory, SDT (Deci \& Ryan, 2000) are two motivational factors that drive an individual to be involved in actions, such as career development. Job satisfaction is an important motivating factor, where in the case of teaching the motivating factor, internal or external, appears to be mixed. Therefore, it cannot be ascertained whether satisfaction is the most important motivational factor that influences teacher participation in forms of professional development. If students 'success as a result of quality teaching is considered as a form of teachers' satisfaction with their work then it emerges as an important factor in terms of gender $(\mathrm{r}=$ .24).This we have tried to do through quantitative research with a sample of teachers. The degree of job satisfaction and the increased demand / need for participation in various forms of continuous professional development assume that they are not reciprocally linked.

The research reveals that motivational factors for teacher professional development, including job satisfaction, as intrinsic motivational factors, are highly heterogeneous. These data add value to the theory of teacher motivation for professional development as well as to the improvement of teacher professional development practices and policies.

A number of studies have been reviewed regarding motivational factors and teachers' satisfaction with work. For the types of motivation are Deci \& Ryan who study in depth the issues of internal and external motivation. According to them, external motivational factors, such as remuneration, pay, and punishment, reduce the effects of intrinsic motivation. It remains for such an experimental study to be conducted with adults to determine if external motivation impairs intrinsic motivation.

Research is quantitative. The data was collected by the questionnaire. The sample consists of 170 teachers belonging to genders, low secondary school, rural and urban school.

Troesch \& Bauer (2017) addressed the issue of job satisfaction but did not address it in terms of motivational factors. Such a link between job satisfaction and professional development has not been sufficiently explored. This research tends to find the link between job satisfaction and professional development, but causal research is needed to determine if job satisfaction affects teacher professional development.

The quantitative approach was used to conduct the research. The data was collected by the questionnaire. The sample consists of 170 teachers belonging to genders, lower secondary school, rural and urban school. The sample selection was random, and consisted of junior high school teachers.

The survey was the main research technique, and the instrument used a questionnaire consisting of two main parts. The first includes teacher demographic data, such as age, gender, work experience, and place of work, village, or city. The second part are statements in which teachers responded to five Likert scales.

From the analysis of the data from the research we reflect some of the main findings. No relevant correlation has been identified between 
the motivational factors and the opinion of the teachers for work satisfaction, or the assessment made at school for the work they are doing. Some important motives for professional development emerge, such as: The need for continuous professional development $(\mathrm{M}=4.35$, $\mathrm{SD}=.85$ ). From this motive, this can be considered intrinsic as well as extrinsic, since other motivations are expected from the professional development, such as improving the position in society, obtaining a license, increasing the payment, but also achieving high success with students.

If teachers' satisfaction that comes as a result of receiving appreciation for their work is high, then each individual will push for higher achievement in his / her career. Higher students' learning achievements cannot be realized without investing in teachers' continuous professional development. School and educational policy should therefore determine modalities that increase the degree of satisfaction at work. The factors that increase the highest level of satisfaction at work will be expressed/displayed in the research results. The concept of 'motivation based on inertia factor' remains to be explored and analyzed more profoundly through qualitative approach.

This research is important for schools and institutions that select models of professional development of teachers.

Keywords: Carrier achievement, intent to change, job satisfaction, motivation, professional development.

\section{ÖĞRETMENLERİN İŞ DOYUMU ARASINDAKİ İLISSKİLERİ VE MESLEKI GELIŞIM İÇIN MOTIVASYONU}

\section{öz}

Yapılan bu araştırmanın amacı, öğretmenlerin yaptıkları çalışmalardan memnun olup olmama durumlarının onları farklı mesleki gelişim biçimlerine katılmaya motive edip etmediğinin anlaşılmasını ve saptanmasını sağlamaktır. Bu bağlamda, araştırma sonucunda, öğretmenleri mesleki gelişime katılmaya teşvik eden önemli faktörler belirlenmiştir. Kendi kaderini belirleme teorisine göre, SDT (Deci ve Ryan, 2000), bireyi kariyer gelişimi gibi eylemlerde bulunmaya sevk eden iki farklı motivasyon faktörü bulunmaktadır:

İș tatmini, önemli bir motive edici / güdüleyici faktör olarak değerlendirilmektedir; motive edici faktörün öğretilmesi ve uygulanması durumunda sürecin içsel veya dişsal bağlamda karmaşık bir şekilde karşımıza çıtığı görülmektedir. Bu nedenle, motive edici faktörün mesleki gelişim biçimlerine katılımı etkileyen en önemli motivasyon faktörü olup olmadığını açık olarak tespit etmemiz mümkün gözükmemektedir. Öğrencilerin kaliteli öğretim sonucunda elde ettikleri başarı, öğretmenlerin çalışmalarından memnun olma şekli olarak kabul edilirse, bu durum cinsiyet açısından önemli bir faktör olarak ortaya çıkmaktadır $(r=.24)$. Öğretmen örneği. İş tatmini derecesi ve sürekli mesleki gelişimin çeşitli biçimlerine katılım talebindeki artış / ihtiyaç, karşılıklı olarak bağlantılı olmadıklarını varsaymaktadır. Yapılan araştırmada dikkat edilen hususlardan en önemlisi araştırmanın nicel 
olmasıdır. Araştırma sonucunda elde edilen veriler anket çerçevesinde elde edilmiştir. Örneklem; 170 öğretmenden oluşmaktadır. Bu 170 öğretmenin belirlenmesinde çeşitli faktörler (cinsiyet, branş / kademe, yaşanılan yer / kırsal ve kentsel) dikkate alınmıştır.

Keywords: Kariyer başarısı, amaç değişim, iş memnuniyeti, motivasyon, profesyönel geliştirme.

\section{Introduction}

There have been a considerable number of researches on the motivation of teachers for work. Research has also been made on job satisfaction / dissatisfaction, or assessment of individual workplace contribution or evaluation of their contribution to achievement of student achievement. This assessment is usually done or should be done by the school principal, colleagues, parents, students, or even relevant institutions outside the school. In Kosovo, it has become a tradition to evaluate every year the best teacher at the school level as well as at the commune and country level. But this motivation and increasing job satisfaction and job-performance of teachers often fuel dissatisfaction and dilemma with regard to the criteria for such a thing. The lack of proper criteria for motivating this kind of teacher causes disappointment, but also frustration.

The issue we are concerned with is a professional development of teachers, what motivates them to professional development in an environment that lacks the objective evaluation criteria and motivation for the work done by teachers. $M$ this research made some effort to find out whether there is any link between work satisfaction and teacher demand for professional development participation. It is normal for an increase in demand for professional development to originate or be based on teacher dissatisfaction with student achievement results. In our research it turns out $(\mathrm{M}=1,44, \mathrm{SD}=.52)$. Or the opposite, the satisfactory results of students as a driver for professional development of teachers $(\mathrm{M}=1.48, \mathrm{SD}=.50)$.

As for the research question about the possible link between the motives for professional development and job satisfaction, or satisfaction with the work of teachers, we have not identified any significant correlations.

\section{Theoretical framework}

Regarding the motivation of teachers, forms and types of motivation, motivational patterns, etc., a series of researches have been conducted and theories have been built, such are, intrinsic and extrinsic motivation (Deci \& Ryan,1985), but also various models for professional development (Guskey, 2002). Also in terms of job satisfaction, or satisfaction with the work, theories and research have been developed both earlier and recently. Different factors that affect the sense of satisfaction at work or work, workplace or even the product or the results of individual work are addressed and researched in these researches. According to Evans (1997), teachers' job satisfaction is mainly individual matter, resulting in heterogeneous levels of job satisfaction among teachers working within same schools' (Maele \& Houte, 2012, p.882). While others feel that there is a dependency, interconnection, between 'natures of the school context influences teachers' job satisfaction' (ibid). Well-known authors of this field emphasize that 'The present study focuses on relations between these school-based factors, which we term contextual variables, and how they relate, both directly and indirectly, to teacher job satisfaction.

The indirect relations that we hypothesize are that the impact of school context variables on job satisfaction is mediated through teachers' feeling of belonging at school and emotional exhaustion (Skaalvik \& Skaalvik, 2011). Also, according to them 'In the research literature, job satisfaction is regarded as the positive or negative evaluative judgments people make about their jobs (Weiss, 2002). 
For instance, Locke (1976) defined job satisfaction as a pleasurable or positive emotional state resulting from the appraisal of one's job. In accordance with these definitions, we conceptualize teacher job satisfaction as teachers' affective reactions to their work or to their teaching role (see Skaalvik \& Skaalvik, 2010a; Zembylas \& Papanastasiou, 2004). Affective reactions, according to Locke, we must see it from a positive perspective, satisfaction with work, or evaluation of his work, but also as a reaction to not evaluating his work, or the dissatisfaction that he or she may have with his or her own contribution or achieved results, but also with working conditions, workload, and the 'job stress' (Troesch \& Bauer, 2017).

Job satisfaction, as a concept, is more comprehensive than the concept that involves teaching or professional development. Research in this area has been done more in the field of economy and production than in the field of education.

By the Troesch \& Bauer (2017) Job satisfaction is defined as "the extent to which people like (satisfaction) or dislike (dissatisfaction) their jobs" (Spector, 1997) or as the "state of mind determined by the extent to which the individual perceives her/his job-related needs to be being met" (Evans, 1997). According to authors "job satisfaction is influenced by external factors such as work conditions as well as internal factors such as self-efficacy beliefs'. (According to Evans, 1997).

While in Tran \& Le's article we find the definition of job satisfaction (citied from Evans, 1997), refers to the degree to which teachers' job-related needs such as fulfillment, gratification, recognition for accomplishments, and satisfaction are being met (according to Tran \& Le 2015). In the same paper, the authors link job satisfaction to other factors such as the working environment, internal motivation and motivation, as can be the reward for the foregoing. Interestingly, my topic also seems to me '...teachers are satisfied with their teaching work such as professional interest, professional growth but dissatisfied with the performance of their job, such as working conditions, interpersonal relation, and salary (Butt at al., 2015) (according to Tran \& Le, 2015). But, regarding to Feather \& Router (2004), Teachers' job satisfaction has relationship with their motivation, wellbeing and commitment to teaching (according to Tran \& Le, 2015) not specifying what kind of motivation it is, extrinsic or intrinsic, or other kind of motivation, such is altruistic motivation etc. While there are other authors who also associate job satisfaction with the efficiency of teaching and stress, for example (Caprara et al 2003), then also (Klasen \& Chiu 2010), according to whom '...stress and teaching efficacy contributed to job satisfaction (according to Tran \& Le, 2015). These authors address the issue of stress on work as a factor that is highly influential in the quality of job satisfaction, but do not correlate with the motivation for professional development, which we are interested in presenting in this research. This is the purpose of this study to see if the motivation of teachers for professional development is related to their satisfaction at work, example, by evaluating their contribution to the work they do with their students.

\section{Research Questions}

Based on the literature, revised studies, the issue of linking motivation to professional development with the level of satisfaction at work has not been addressed. Other factors have been addressed, such as teaching efficiency, peer relationships or other environmental and social factors at school, but not the relationship between motivation for professional development and job satisfaction, or job satisfaction and motivation for professional development. Therefore, based on the literature mentioned above, browsing, and the present study will try giving answer in the following questions:

RQ 1: Is there a significant link between teacher motivation for professional development and job satisfaction?

RQ 2: What is the opinion of the teachers about the link between Motivations for Professional Development with the Assessment of His Work at School? 

development?

RQ 3: What are the main factors influencing the motivation of teachers for professional

\section{Method}

In this is study we used a quantitative research approach. It's designed to identify the opinions of teachers about the significance of motivation for professional development and job satisfaction. Through this research we try to examine whether there is a possible link between motivation for professional development, type of motivation and job satisfaction of teachers. Participants in the research were teachers from different schools, low high school (6-9). At the beginning we have compiled a questionnaire than piloted on a sample of 30 different teachers by age, profession and school where they work. After reviewing the questionnaire we made corrections and necessary changes. Then we have selected 34 schools from seven regions of Kosovo, according to the criteria: from each school five teachers, both gender, from urban and rural school, different ages and who have attended professional development training. In 17 schools, we have dispatched the questionnaire, while in 17 we sent it to by e-mail to one teacher, who then shared it with four other colleagues. Then individually they sent me, filled in my address. I did not notice any significant difference between the teachers who completed the questionnaire, pens-paper, and the ones they did in the electronic version.

\section{Sample}

The research sample consisted of $(\mathrm{N}=170)$ teachers, from 34 low secondary school from seven Kosovo's Region. In total 81 are female, or $53.5 \%,(\mathrm{SD}=.4983, \mathrm{M}=1.438)$, and 79 male, or $46.5 \%$ (SD.05016, M=1.510). From Urban schools were 92 teachers or $54.1 \%$ and from rural schools 78 or $45.9 \%,(\mathrm{SD}=.49977, \mathrm{M}=1.4588)$. The average years of teaching experience for participants distributed by years, as seen in bellow Table 1. They are divided on 8 levels of experiences $(\mathrm{SD}=$ 2.014, $\mathrm{M}=3.33$ ). As we see in bellow table most of them were in first level of experiences 1-5 years, or $22.9 \%$.

Table 1: The sample characteristics, by experiences

$\begin{array}{llll} & \text { Frequency } & \text { Percent } \\ \text { Valid } & \text { From 1-5 years } & 39 & 22.9 \\ \text { From 6-10 years } & 31 & 18.2 \\ \text { From 11-15 years } & 31 & 18.2 \\ \text { From 16-20 years } & 25 & 14.7 \\ \text { From 21-25 years } & 14 & 8.2 \\ \text { From 26-30 years } & 14 & 8.2 \\ \text { From 31-35 years } & 10 & 5.9 \\ \text { More than 36 years } & 6 & 3.5 \\ \text { Total } & 170 & 100.0\end{array}$

\section{Research Instrument}

We have conducted the research with a questionnaire. The structure of the questionnaire consists of the demographics of the participants and the questions. There are 25 topics in total. From demographic data, first part, we have asked for gender, place where he works, experience as a teacher, participation in trainings and how they participated in those trainings, or invitation. The questionnaire consists of three main parts. The first part includes the demographic data of teachers. The second part 
consists of potential motivating factors for professional development and the third part the situations in which the teacher feels pleasure at work, or appreciates the contribution of his work to school.

For the potential motivating factors for the professional development of teachers, they have made their rankings five-degree, from 1 . Very low motive, to 5 . Motive very high.

\section{Teachers' motivation for Professional development}

By the questionnaire we have researched the number of trainings attended by the teachers as well as the manner of (invitation) of the participation. Regarding the forms of teacher motivation for professional development, or for partitioning into different forms of professional development, we have included a total of 16 incentives, potential motivators, which teachers have ranked on five levels: 1. very low motive, 2. low motive, 3. neutral motive, 4. high motive, and 5. Very high motive. Teachers are asked to present their opinion on how each of these forms of motivation is placed on the professional development participation. The first demand was the needs of teachers for professional development. The task of teachers has been that the need for professional development determines at which level of motivation they are part of 1-5. While the second requirement is part of the external motivation 'taking or pursuing a course' as an administrative obligation for each teacher. Another requirement or need for professional development was 'risk of losing the job' which is current today when the number of pupils in the school is falling, and therefore the risk of being left out of work. Similarly, we have also acted with the following requirements, such as: 'salary increase', one of the external motives, 'increasing authority in society' as an internal motive, being 'equal to colleagues', then another motive' achieving success with students' which can be included in the internal or even altruistic motive, 'advancement in a position' as a motivation for self-actualization, 'the director's request' for attending the training as a more neutral motive or impulse such as 'encouragement by colleagues' or 'because everyone is going because I do not,' a kind of 'motivation of inertia' while demands for professional development due to' curriculum changes' as a necessity along with 'tracking developments in technology', as well as 'need for change' or 'exchange of experiences with other colleagues' or from other schools.

\section{Job satisfaction}

The third part of the instrument has only requirements related to job satisfaction and the need or desire for professional development. In the job satisfaction claim "If I was satisfied (if I am satisfied) with the work I do at school, then: 1 . I would constantly seek professional development; 2. Sometimes I would seek professional development; 3. I would not need professional development; 4. I appreciate my assessment at school. The demand for teachers was to choose only one alternative. As to the question: Do you think the school appreciates your professional contribution with the students? They have had to choose between alternatives: 1 . Fare does not evaluate my work at school; 2 . Sometimes, as appropriate; 3. Often I feel satisfied with the evaluation of my work, 4. Regularly received positive evaluations. Regarding the assessment of their work in the school as a motivator / motivator for professional development, we have asked to express the degree of satisfaction in five levels: 1. I disagree; 2. partially agree; 3. Agree; 4. Partially agree; and 5. Fully agree. The last question was a direct request for motives or incentives for professional development, where they selected one of eight alternatives, such as: satisfaction with the work they do; my dissatisfaction with the evaluation of my job; the evaluation of my work encourages me for higher successes; the success of the students pushed me to develop; my students' absence is worrisome, so I'm looking for new professional experiences; to coincide with successful college students; to track developments in technology, to be more successful. All of these in the statistical analysis we found correlations or not.

\section{Procedure}

These entire 34 Low Secondary School teachers were participate in this study after the permission for access to the study was obtained from the principals of schools. All participants were 
clearly explained that they were free to withdraw from the research at any time. The privacy of participants was ensured concerning the information they supplied in the questionnaires. No questions or statements required the participants to provide their names and schools where they are teaching. Data were collected during the beginning in October 2017 and ending in January 2018. Participants completed the questionnaire, approximately 25 minutes.

Since the way the data collected, the response rate was almost 100 percent for those teachers.

\section{Data Analysis}

The relationships among predictor variables - job satisfaction, and outcome variable teachers motivation for professional development, were investigated using the Pearson correlation coefficient. In addition, multiple regression analyses were conducted to determine if there were any associations among predictor variables and outcome variables. The relationships among outcome variables were also investigated. For all tests, the significance level was determined with $p<.05$.

\section{Results}

Based on the analysis of the results we have identified seven main motives which push the teachers for professional development. Three are from the part of satisfaction with work and five from other.

Table 2: Main factors that motivate teachers to participate in professional development

\begin{tabular}{|c|c|c|c|}
\hline Motivations type & Mean & Std. Deviation & $\mathrm{N}$ \\
\hline The need for continuous professional development & 4.3588 & $\mathbf{8 5 3 5 1}$ & 170 \\
\hline Providing a license & 3.9706 & 1.11698 & 170 \\
\hline Risk of losing the job & 2.8941 & 1.40602 & 170 \\
\hline Increase of salary & 3.4824 & 1.31996 & 170 \\
\hline Increase of authority in the community / society & 3.4529 & 1.22142 & 170 \\
\hline Equalizing with colleagues & 3.4118 & 1.17462 & 170 \\
\hline Achieve the highest success with students & 4.6294 & .83437 & 170 \\
\hline Advancing to any other position & 3.5882 & 3.34166 & 170 \\
\hline Follow up on technology development & 4.3059 & .97936 & 170 \\
\hline The director's request & 3.3353 & 1.13546 & 170 \\
\hline Changes in the Curriculum & 4.0647 & 1.14170 & 170 \\
\hline Encouragement by colleagues & 3.2059 & 1.13522 & 170 \\
\hline Fulfillment of shortcomings from previous education & 3.6882 & 1.23191 & 170 \\
\hline Everyone is being trained, why not. & 2.5118 & 1.26976 & 170 \\
\hline Knowing the experiences of others, sharing experiences & 4.2588 & .91862 & 170 \\
\hline Need for change & 4.4000 & .80236 & 170 \\
\hline $\begin{array}{l}\text { If I was concerned with my job, I would seek professional } \\
\text { development }\end{array}$ & 1.3059 & .66214 & 170 \\
\hline The school appreciates my contribution with students & 2.7000 & .85554 & 170 \\
\hline $\begin{array}{l}\text { If you are satisfied with evaluating your work, do you motivate } \\
\text { this for professional development? }\end{array}$ & 3.9882 & 1.24505 & 170 \\
\hline Main factors that Motivate for Professional Development. & 3.8235 & 2.47437 & 170 \\
\hline
\end{tabular}

In the last, the demand for teachers has been to make the identification of the main motivation factors to participate in professional development. Out of all eight factors, they had to choose one that is most important to them. As seen in Table 2, we have a very heterogeneous distribution of the determinant factor for professional development of teachers.

'The need for continuous professional development' with the 'very high motivation' rating being estimated by $51.8 \%$ of teachers, 'high motivation' $38.2 \%$, and viewed by gender we have ( $\mathrm{M}=$ $4.35, \mathrm{SD}=.85$ ), which does not differ from the common evaluation. 'Advancing to any other position' as shown in the table is the lowest rated rating. Of $\mathrm{N}=170$ only $18.2 \%$ consider it as 'very high 
motive', 28.8 as 'high motive' and most of them, or $32.4 \%$ have a neutral attitude to this motive $(\mathrm{M}=3.58, \mathrm{SD}=3.34)$.

On the Table 3. Shown the main teachers' motivation to participate in professional development $(\mathrm{M}=3.82, \mathrm{SD}=2.47)$.

Table 3: Most frequently motivation factors, ranking by teachers

\begin{tabular}{|c|c|c|c|c|c|}
\hline & & Frequency & Percent & Valid Percent & $\begin{array}{l}\text { Cumulative } \\
\text { Percent }\end{array}$ \\
\hline \multirow{9}{*}{ Valid } & & & & & \\
\hline & Satisfaction with my Job & 46 & 27.1 & 27.1 & 28.8 \\
\hline & $\begin{array}{l}\text { The dissatisfaction I have } \\
\text { with appreciate of my work. }\end{array}$ & 1 & .6 & .6 & 29.4 \\
\hline & $\begin{array}{l}\text { Appreciation of my job } \\
\text { pushes me for higher } \\
\text { success. }\end{array}$ & 25 & 14.7 & 14.7 & 44.1 \\
\hline & $\begin{array}{l}\text { Outcomes of my students } \\
\text { push me for development. }\end{array}$ & 50 & 29.4 & 29.4 & 73.5 \\
\hline & $\begin{array}{l}\text { The failure of my students } \\
\text { worries me, so I'm looking } \\
\text { for new experiences. }\end{array}$ & 9 & 5.3 & 5.3 & 78.8 \\
\hline & $\begin{array}{l}\text { Get equal with successful } \\
\text { colleagues. }\end{array}$ & 3 & 1.8 & 1.8 & 80.6 \\
\hline & $\begin{array}{l}\text { To keep up with } \\
\text { developments in technology } \\
\text { to be more successful }\end{array}$ & 33 & 19.4 & 19.4 & 100.0 \\
\hline & Total & 170 & 100.0 & 100.0 & \\
\hline
\end{tabular}

As shown in Table 2, as higher motivational motivating factors, for professional development, teachers have identified 'student success' $(\mathrm{M}=1.48, \mathrm{SD}=.50)$, while second place lists' satisfaction with work that motivates me for professional development ' $(\mathrm{M}=1.54, \mathrm{SD}=.50)$. Third place is the motive of 'pursuing technology development to be more successful' $(\mathrm{M}=1.60, \mathrm{SD}=.49)$, while fourth is ranked 'evaluating teacher's work by others, which promotes for further development $(\mathrm{M}=1.56, \mathrm{SD}=.50)$. But with lower frequency, there is 'the dissatisfaction the teachers have with the evaluation of their work by others'.

An analysis using Pearson's correlation coefficient (Table 4) shown that the bivariate correlations between demographic variables, gender, experiences, place where they teach, and job satisfaction as shown in table below. Only one potential factor has not been chosen by any of the teachers, though in piloting more than half have identified as a potential factor, such as 'To be distinguished from unsuccessful colleagues in student work'. 
Table 4: Correlation between gender, place and experiences with job satisfaction factors

\begin{tabular}{|c|c|c|c|c|c|c|c|}
\hline & & Gender & Place & $\begin{array}{l}\text { Experien } \\
\text { ce }\end{array}$ & $\begin{array}{l}\text { Achieve } \\
\text { the } \\
\text { highest } \\
\text { success } \\
\text { with } \\
\text { students }\end{array}$ & $\begin{array}{l}\text { The school } \\
\text { appreciates } \\
\text { my } \\
\text { contribution }\end{array}$ & $\begin{array}{l}\text { Main } \\
\text { motives } \\
\text { for PD. }\end{array}$ \\
\hline \multirow[t]{3}{*}{ Gender } & $\begin{array}{l}\text { Pearson } \\
\text { Correlation }\end{array}$ & 1 & $-.160^{*}$ & $-.241^{* *}$ & -.117 & -.024 & .034 \\
\hline & $\begin{array}{l}\text { Sig. (2- } \\
\text { tailed) }\end{array}$ & & .037 & .002 & .128 & .761 & .662 \\
\hline & $\mathrm{N}$ & 170 & 170 & 170 & 170 & 170 & 170 \\
\hline \multirow[t]{3}{*}{ Place } & $\begin{array}{l}\text { Pearson } \\
\text { Correlation }\end{array}$ & $-.160^{*}$ & 1 & -.081 & .098 & .061 & -.011 \\
\hline & $\begin{array}{l}\text { Sig. (2- } \\
\text { tailed) }\end{array}$ & .037 & & .297 & .204 & .430 & .890 \\
\hline & $\mathrm{N}$ & 170 & 170 & 170 & 170 & 170 & 170 \\
\hline \multirow[t]{3}{*}{ Experiences } & $\begin{array}{l}\text { Pearson } \\
\text { Correlation }\end{array}$ & $-.241^{* *}$ & -.081 & 1 & -.082 & .102 & .038 \\
\hline & $\begin{array}{l}\text { Sig. }(2- \\
\text { tailed) }\end{array}$ & .002 & .297 & & .289 & .184 & .624 \\
\hline & $\mathrm{N}$ & 170 & 170 & 170 & 170 & 170 & 170 \\
\hline \multirow[t]{3}{*}{$\begin{array}{l}\text { Achieve the highest success } \\
\text { with students }\end{array}$} & $\begin{array}{l}\text { Pearson } \\
\text { Correlation }\end{array}$ & -.117 & .098 & -.082 & 1 & .067 & .023 \\
\hline & $\begin{array}{l}\text { Sig. (2- } \\
\text { tailed) }\end{array}$ & .128 & .204 & .289 & & .384 & .770 \\
\hline & $\mathrm{N}$ & 170 & 170 & 170 & 170 & 170 & 170 \\
\hline \multirow[t]{3}{*}{$\begin{array}{l}\text { School appreciate my } \\
\text { contribution }\end{array}$} & $\begin{array}{l}\text { Pearson } \\
\text { Correlation }\end{array}$ & -.024 & .061 & .102 & .067 & 1 & .000 \\
\hline & $\begin{array}{l}\text { Sig. }(2- \\
\text { tailed) }\end{array}$ & .761 & .430 & .184 & .384 & & 1.000 \\
\hline & $\mathrm{N}$ & 170 & 170 & 170 & 170 & 170 & 170 \\
\hline \multirow[t]{3}{*}{$\begin{array}{l}\text { Main factors that motivate for } \\
\text { professional development }\end{array}$} & $\begin{array}{l}\text { Pearson } \\
\text { Correlation }\end{array}$ & .034 & -.011 & .038 & .023 & .000 & 1 \\
\hline & $\begin{array}{l}\text { Sig. (2- } \\
\text { tailed) }\end{array}$ & .662 & .890 & .624 & .770 & 1.000 & \\
\hline & $\mathrm{N}$ & 170 & 170 & 170 & 170 & 170 & 170 \\
\hline
\end{tabular}

*. Correlation is significant at the 0.05 level (2-tailed).

**. Correlation is significant at the 0.01 level (2-tailed).

Based on the Table 4, above, we can talk about significant correlations between variables. If we refer to the altruistic motive, achieving success with students, we see there are differences between genders: example for the male, $(\mathrm{M}=3.66, \mathrm{SD}=1.74)$, and for female $(\mathrm{M}=3.8, \mathrm{SD}=1.57)$, but for both gender we have $(\mathrm{M}=4.63, \mathrm{SD}=.83)$.

\section{Discussion}

From the analysis of the data from the research we reflect some of the main findings. No relevant correlation has been identified between the motivational factors and the opinion of the teachers for work satisfaction, or the assessment made at school for the work they are doing. Some important motives for professional development emerge, such as: The need for continuous professional development ( $\mathrm{M}=4.35, \mathrm{SD}=.85)$. From this motive, this can be considered intrinsic as well as extrinsic, since other motivations are expected from the professional development, such as 
improving the position in society, obtaining a license, increasing the payment, but also achieving high success with students.

Another motivating factor of average importance identified is also 'Achieve the highest success with students' $(\mathrm{M}=4.6294, \mathrm{SD}=.834)$. From the data we can see that this is the main reason evaluated by the teacher $(\mathrm{N}=170$, of which $74.7 \%$ consider 'very high motive' and $19.4 \%$ 'high motive'). While in the request to identify one of the eight motivational factors to participate in professional development, we have a different distribution, $(\mathrm{M}=3.82, \mathrm{SD}=2.47)$, expressed in percentages is as follows: 'Success of students pushed me to develop further (29.4\%),' satisfaction with work that makes' (27.1\%), 'to follow the developments in technology to be the most successful' (19.4\%), but only $5.3 \%$ of them as a motivation for professional development see "the lack of students worries me so I look for new experiences'.

There are two elements of the research, though not so much expressed, 'Everyone is being trained, why I do not' $(\mathrm{M}=2.51, \mathrm{SD}=1.26)$ this I call it a phenomenon based on the motive of inertia ('motivation by inertia') without having any particular purpose or objective which is based on the need for professional development. Expressed in percentage this looks like this: $12.9 \%$ consider 'high motivation' and $7.1 \%$ 'very high motive'.

\section{Importance of results}

About $75 \%$ of the teachers as the highest motive consider achieving success with students. They express this motive as opportunities for continuous professional development. In the ranking of motivational factors, achievement of success with students falls to $29 \%$ of the declarations. But only about 5\% of teachers as a motivational factor for professional development consider the 'failure of their students'. This, we think, should be the main driving force, and the need for continuous professional development on the part of the teachers. Job satisfaction, or work at school, is not an important motivational factor for professional development. Only about $15 \%$ consider it important.

This research is important for schools and institutions that select models of professional development of teachers.

\section{Further research}

From the research it can be seen as very controversial the link between job satisfaction and motivation for professional development of teachers in Kosovo. It remains to be explored as a matter of particular satisfaction at work, but also the motivational factors identified in this research. The issue of professional development participation 'based on' the 'inertia' motive, 'everyone is going, why I do $n o t$ ' remains to be treated and explored through qualitative approach.

\section{Acknowledgment}

For teachers who agreed to answer the questionnaire, the schools that enabled me to access and the colleagues who helped me through the data collection process!

\section{REFERENCES}

Guskey, Th. R. (2002). 'Professional Development and Teacher Change', Teachers and Teaching: Theory and practice, Vol. 8, No. 3/4,381 - 391 To link to this Article: DOI: 10.1080/135406002100000512, URL: http://dx.doi.org/10.1080/135406002100000512.

Klassen, R. M., \& Chiu, M.M. (2010). Effects on teachers' self-efficacy and job satisfaction: Teacher gender, years of experience, and job stress. Journal of Educational Psychology, 102, 741-756. http://dx.doi.org/10.1037/a0019237. 
Maele, D.V.,\& Houtte, M.V. (2012). The role of teacher and faculty trust in forming teachers' job satisfaction: Do years of experience make a difference? Teaching and Teacher Education, 28 (879-889)

Menon, M. E. \& Saitis, C. (2006). Satisfaction of Pre-service and In-service Teachers with Primary School Organization, Educational Management Administration \& Leadership ISSN 17411432 DOI: 10.1177/1741143206065269, SAGE Publications (London, Thousand Oaks and New Delhi), downloaded, 13.01.2018.

Pappas, E. (2015). A Theory of Intrinsic Learning: Fundamental Concepts, Social Science Today Volume 2, Issue 1 (2015), 21-32 ISSN 2368-7169 E-ISSN 2368-7177 Published by Science and Education Centre of North America. Downloaded, 12.01.2018.

Ryan, R. M., Deci, E. L. (2000). Self-determination Theory and the facilitation of Intrinsic motivation, Social development, and well-being, American Psychological association, Vol.55, No 1, 6878.

Sansone, C., Harackiewicz, J. M.(2000). Intrinsic and Extrinsic Motivation, The Search for Optimal Motivation and Performance, Academic Press, California, USA.

Skaalvik, E. M.,(1997). Self -enhancing and self-defeating Ego orientation: Relations with task and avoidance orientation, achievement, self-perceptions, and anxiety, Journal of educational Psychology Vol.89, No 1, p.71-81.

Skaalvik, E.M., Skaalvik S. (2011). Teacher job satisfaction and motivation to leave the teaching profession: Relations with school context, feeling of belonging, and emotional exhaustion, Teaching and Teacher Education 27 (1029-1038).

Stride, C. , Wall, T. D., Catley, N.,2end edit. (2007). Measures of job Satisfaction, Organizational Commitment, mental Health and Job-related Well-being, John Wiley \& Sons Ltd, England.

Tran, V. D. \& Le, M. T. L. (2015). School Environment Factors as Predictors for Teachers' Teaching Efficacy, Teacher Stress and Job Satisfaction, International Education Research Volume 3, Issue 2 (2015), 28-46 ISSN 2291-5273 E-ISSN 2291-5281 Published by Science and Education Centre of North America, download 13.01.2018.

Troesch, L.M., Bauer, C. E. (2017). Second career teachers: Job satisfaction, job stress, and the role of self-efficacy, Teaching and Teacher Education, 67 (389-398).

Wasserman, E.\& Maymon, Z. (2017). The Correlation between Professional Development and Teacher's Self-Efficacy, International Education Research Volume 5, No. 1 (2017), 1-12 ISSN 2291-5273 E-ISSN 2291-5281 Published by Science and Education Centre of North America, downloaded 12.01.2018. 